\title{
USING MONTE CARLO SIMULATION AS A FINANCIAL MODELING TOOL TO SUPPORT SUSTAINABILITY EFFORTS OF A GOVERNMENT AGENCY
}

\author{
KARYL B. LEGGIO (corresponding author) \\ Department of Finance \\ Loyola University Maryland \\ Baltimore, Maryland, U.S.A. \\ kbleggio@loyola.edu \\ C. REID NICHOLS \\ Marine Information Resources Corporation \\ Ellicott City, Maryland, U.S.A. \\ rnichols@mirc-us.com
}

\begin{abstract}
The National Oceanic and Atmospheric Administration (NOAA) collects ecosystem data to support coastal resource conservation and management activities by studying stressors that impact estuaries such as the Chesapeake Bay, which is the largest in the United States. This paper seeks to help NOAA justify its existence and its budget by utilizing Monte Carlo simulation as a financial modeling tool, with such simulations providing insights on how to allocate identified resources. The results of the study offer an innovative method for helping government managers decide how much money to spend, what to spend it on, and how to acquire resources for the Chesapeake Bay Interpretive Buoy System. Moreover, this paper also demonstrates how an experiential project in graduate business education can be used to support sustainability efforts by addressing community-focused issues while improving student connection between theory and application at the same time.
\end{abstract}

\section{KEYWORDS}

environmental sustainability; Monte Carlo simulation; financial modeling; government funding 


\section{PURPOSE OF THE STUDY}

Experiential learning has become increasingly popular as a means for assisting students in the mastery of concepts and retention of content. Such is the case in graduate business education where students can aim to create value for their organizations by fulfilling course requirements framed in terms of addressing a company need. This paper discusses one such experiential learning project, one that supports efforts to protect and preserve the Chesapeake Bay, which produces 500 million pounds of seafood annually and supports two out of five major shipping ports in the North Atlantic. It is an attempt to assist the Chesapeake Bay Office, which is part of the National Marine Fisheries Service of the National Oceanic and Atmospheric Administration (NOAA), in recognizing the potential value that is present within the confines of the annual congressional budget allocation for the agency.

In 2016, the Association to Advance Collegiate Schools of Business (AACSB) formulated a collective vision for business education. They identified one of five drivers for change as business schools becoming enablers for global prosperity (AACSB International, 2016). Business is about more than just wealth creation; it is a vehicle for having an impact in the creation of a better, more sustainable world. The AACSB notes the need for business schools to innovate and for business schools and the business community to have a positive impact upon society.

\footnotetext{
The future calls for business schools to capitalize on academic strengths in order to grow and develop the rich space between theory and practice in ways that positively impact society. To do so, schools will need to pursue operational models and strategies that firmly position themselves at the intersection of industry and practice, as conveners and partners in the knowledge creation ecosystem rather than just suppliers. (AACSB International, 2016)
}

The content taught in business schools, along with the research created by faculty in the academy, can thus be integrated to address global issues. This is not simply a nice idea-it is becoming the expectation of our students, the business community, and our accreditation organizations. Numerous researchers (Jamison, Hanushek, Jamison, \& Woessmann, 2008; Kim, Tamborini, \& Sakamoto, 2015; Tamborini, Kim, \& Sakamoto, 2015) have described the importance of lifelong learning and demonstrated the value of education and training in sustaining a healthy economy. 
In the context of this new perspective on business schools, it is imperative that graduate education today helps participants learn new skills that will aid them in making a difference both in their firms and in the world. The Assurance of Learning Standards conceptualized by AACSB focuses on learning outcomes, asking the question, "What will our students learn in our program?" (AACSB International, 2007). At Loyola University Maryland's Sellinger School of Business, the Professional's MBA is customizable and explicitly enables students to acquire a broader perspective of their organization as they gain real-world experience from visits to organizations and meetings with business leaders. Students will learn in an environment where they can explore new ways of thinking and acquire a deeper proficiency in the relationships that power successful organizations, helping them emerge as confident, competent leaders. This approach to graduate business education is value-centered and focuses on an ethical commitment that manifests itself in a series of learning goals designed to encourage student-based experiential learning.

Creating an often-new-to-the-organization means of deriving recommendations in support of a project, as is done by incorporating into research the available databases and tools that were learned in the classroom, is the goal behind pursuing student-based research projects within the curriculum. The experiential learning project discussed in this paper involves the development of a system that uses Monte Carlo simulation to justify the expense of the Chesapeake Bay Interpretive Buoy System (CBIBS; see http://buoybay.noaa.gov/) based on the value created by the data that was generated from the instrumented buoys.

\section{DESIGN AND METHODOLOGY}

The system that would become a financial modeling tool was developed in the context of a graduate course in finance (GB 719) the objectives of which were to 1) study capital budgeting models, 2) build a financial model, and 3) work with data from an existing organization. The course began with a review of the applications of financial decision tools such as payback period, net present value (NPV), internal rate of return (IRR), and profitability index before moving into learning new ones such as Monte Carlo simulation for valuation, a tool which had been previously used in other student case studies (Stretcher, 2015). Monte Carlo simulation allows students to build a tractable model that provides valuable information to the 
decision maker. It can be used to determine how sensitive a system is to changes in variables or operating conditions as well as an optimal operating policy or distribution of resources (Winston, 1996). Company-specific projects are thus good platforms for applying Monte Carlo simulation since students will be using a new technique on familiar data-that gathered from within their firms or market areas. Research shows that student learning is enhanced when the work is relevant to their lives both inside and outside of the classroom (Kuh, 2016).

Projects are segmented into a series of deliverables to make them more manageable for students; increase the faculty member's familiarity with the student's company, market, and project as the semester progresses; and assure that the student is on track through feedback provided by the faculty member prior to a final submission.

The first deliverable for this project is an overview of the firm and market which, in this case, is complicated by the fact that NOAA's budget is set by Congress and has been declining in recent years.

\section{PROJECT BACKGROUND}

Founded in 1970, the National Oceanic and Atmospheric Administration (NOAA) is an agency of the U.S. Department of Commerce whose mission is to understand and predict changes in climate, weather, the oceans, and coasts; share that knowledge and information with others; and conserve and manage coastal and marine ecosystems and resources. Dedicated to the understanding and stewardship of the environment, NOAA has been a partner in the multi-state and multi-agency Chesapeake Bay Program which works to protect and restore the Chesapeake Bay through ecosystem science, coastal and living resource management, and environmental literacy. Their Chesapeake Bay Office (NCBO) supports NOAA's National Estuarine Research Reserves (NERRS) network, a system of 28 coastal sites designated for the protection and study of estuarine systems. NERRS has also developed partnerships within and outside of NOAA, such as with the National Parks Service and Environmental Protection Agency (EPA).

The NCBO fulfills its statutory mandate through multi-species fisheries research, habitat characterization and assessment, community engagement and outreach, and 
coordination of NOAA activities under Executive Order (EO) 13508, Chesapeake Bay Protection and Restoration, which was issued in 2009. This EO states that the Chesapeake Bay Office shall "provide technical assistance on processes impacting the Chesapeake Bay system, its restoration and habitat protection; develop a strategy to meet the commitments of the Chesapeake Bay Agreement; and coordinate programs and activities impacting the Chesapeake Bay, including research and grants." The Agreement focuses on collaboration and coordination in watershed restoration and protection efforts.

The NCBO accomplishes its mission with personnel from several contractors as well as from NOAA's Fisheries Service, the National Ocean Service, and the National Environmental Satellite, Data, and Information Service.

NCBO's operations include the Chesapeake Bay Interpretive Buoy System (CBIBS) which was implemented in 2007. The CBIBS observation network provides users with information on wind speed and direction, wave measurements, dissolved oxygen, chlorophyll, and turbidity. These measurements provide the data necessary for improving marine forecasts which support commercial transportation, fishing, and recreational boating on the Chesapeake Bay. The growing database also provides information needed for monitoring the health of the Bay. Observations from the buoys are used in educational settings, and buoys mark locations along the National Park Service's Captain John Smith Chesapeake National Historic Trail (National Park Service, n.d.). Finally, software applications that allow users to obtain real-time weather and environmental information at any buoy location, such as wind speed, temperature, and wave height, are also available.

CBIBS supports watershed benefits such as fisheries and tourism which are estimated to be worth $\$ 4.6$ billion annually in Maryland's Chesapeake Bay region (Phillips \& McGee, 2014). To ensure high quality data, field technicians who understand the CBIBS system must be capable of completing diagnostics and repair in both the field and the laboratory. CBIBS buoys require monthly scheduled maintenance, semi-annual refurbishment, and an unpredictable amount of unscheduled maintenance (to repair or replace a broken cable or sensor, for example). Routine tasks include removing biofouling from buoy hulls and transducers, cleaning and replacing solar panels, and conducting mooring inspections, among others. 


\section{DETERMINATION OF ECONOMIC VALUE}

Since there are no direct revenues associated with the purpose of this study, the value added by the agency's existence to constituents was estimated with the help of data gathered from various agencies and from previous studies that quantified the value of the agency's work.

Appropriations to the $\mathrm{NCBO}$ for each of the fiscal years from 2006 through 2016 totaled approximately $\$ 6,000,000$. Figure 1 provides an estimate of this funding (NOAA Budget Office, n.d.). Buoys cost approximately $\$ 150,000$ each (an operational CBIBS buoy deployed in the Severn River is pictured in Figure 2). Four buoys were lost due to ice damage during the winter of 2014-2015 (the impact of extreme winter weather on the Potomac Buoy is depicted in Figure 3). Estimated expenses are provided in Table 1.

\section{NCBO AND CBIBS BUDGET}

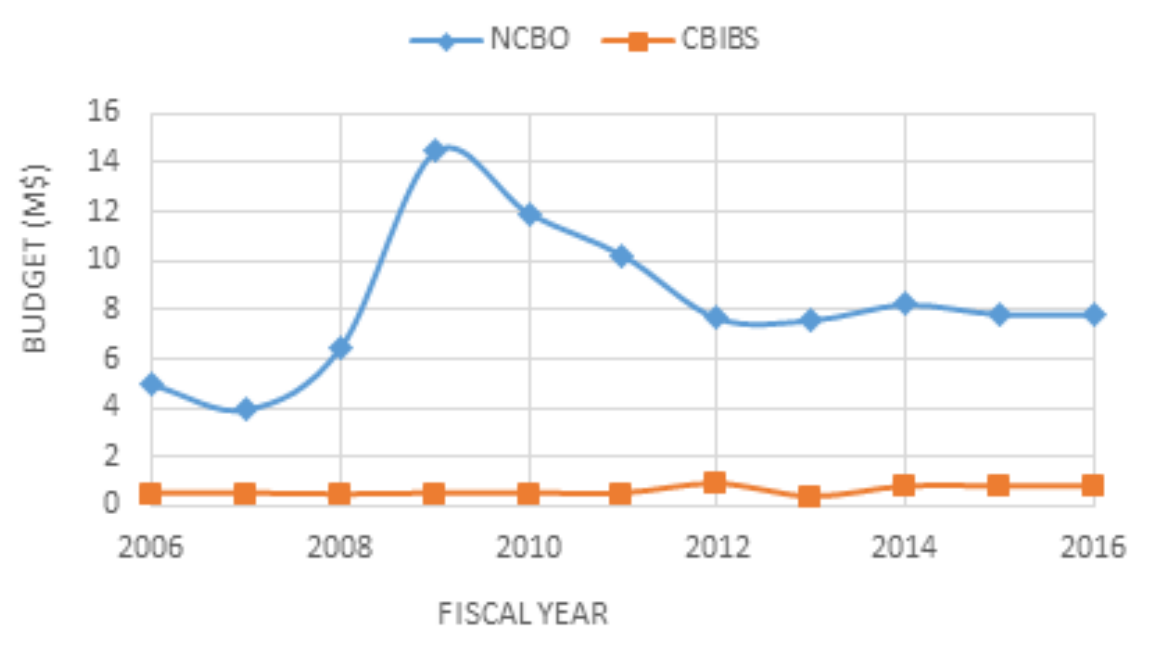

Figure 1: CBIBS budget fluctuations. While the CBIBS budget is steady at approximately $\$ 8$ million per year, events such as collisions and severe weather can cause unbudgeted buoy destruction. 


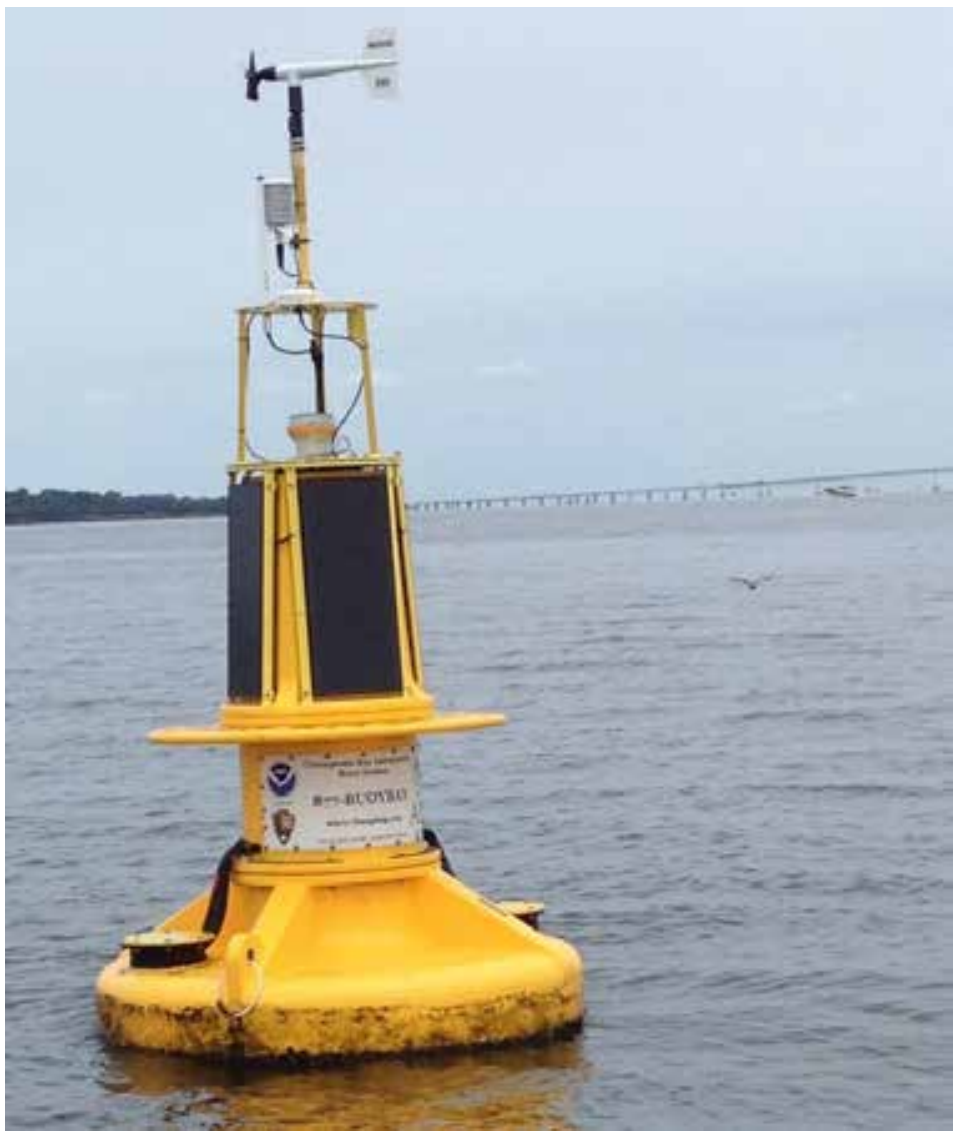

Figure 2: Annapolis CBIBS buoy deployed near the mouth of the Severn River. (Photo courtesy of C. Reid Nichols) 


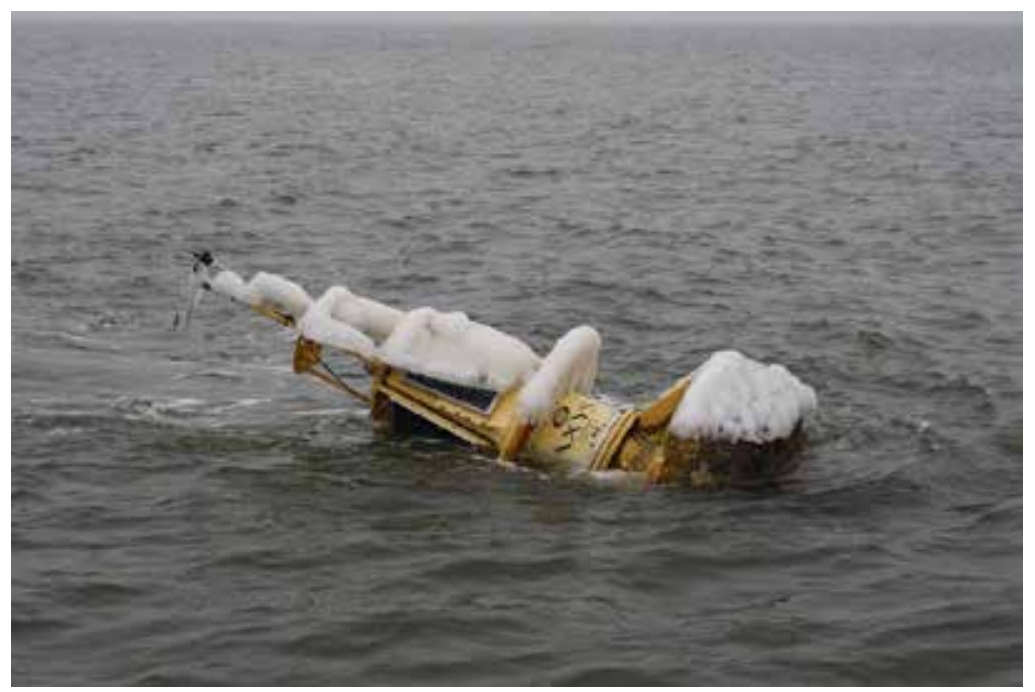

Figure 3: The impact of ice loading on a CBIBS buoy like this one in the Potomac River can confound measurements and destroy sensors. Ice floes can also drag the buoys out of position. (Photo courtesy of NOAA)

\begin{tabular}{|l|l|l|}
\hline \multicolumn{1}{|c|}{ Item } & \multicolumn{1}{|c|}{ Expenses } & \multicolumn{1}{c|}{ Remarks } \\
\hline $\begin{array}{l}\text { Vessel } \\
\text { Operations }\end{array}$ & $\$ 150,000$ & $\begin{array}{l}\text { Ships such as the M/V John C. Widener are } \\
\text { used to recover and redeploy buoys. }\end{array}$ \\
\hline MARACOOS & $\$ 150,000$ & $\begin{array}{l}\text { Data Management, Research \& Development } \\
(R \& D), \text { Consultants }\end{array}$ \\
\hline CRC & $\$ 300,000$ & R\&D, Buoy Maintenance \\
\hline Salaries & $\$ 200,000$ & NOAA and Consultants \\
\hline $\begin{array}{l}\text { NCBO may move various amounts of money to meet operational and maintenance } \\
\text { needs as research and development is completed. Monies on the order of } \$ 20,000 \\
\text { per year, for example, may be available for new components and buoys as data } \\
\text { management software is completed and vessel operations are reduced. }\end{array}$ \\
\hline
\end{tabular}

Table 1: Estimated CBIBS expenses.

Based on the numbers provided by NCBO, there is an overall decline in budget which may be complicated by the need to maintain ageing CBIBS buoys. The system at present includes ten networked data collection buoys that are sited throughout the Bay. These buoys and their sensors require routine maintenance as well as the ability to procure supplies from manufacturers and/or vendors of buoy components. NCBO 
as such maintains several contracts with multiple vendors who supply appropriate buoys, basic sensors, spare parts, and consumable materials. To control costs and ensure efficiency of maintenance as CBIBS expands, buoys added to the core system must be consistent to the greatest possible degree with the standard platform and complement of sensors currently in use.

Cost management also needs to consider contingency funding on an annual basis for at least one spare replacement buoy and an inventory of spare parts based on usage history. If the CBIBS program were to be downsized, buoys could be removed from the water and stored until repurposed or otherwise re-appropriated to another agency or organization (Wheeler, 2012). Some cost savings can be achieved by eliminating stations; others pertaining to salaries, equipment, website expenses, and facilities are fixed and cannot be scaled. These amount to an estimated $\$ 450,000$ per year. The CBIBS program, on the other hand, may maintain its utility and operate for many years. According to the NCBO, for instance, financial resources to replace aging buoy components will be made available through more efficient use of vessel services and the elimination of a costly data management contract. Partners such as Virginia Commonwealth University (VCU) and Dominion Virginia Power might also deploy or donate similar instrumented buoys that can display observations through the CBIBS portal.

The presidential budget for fiscal year 2017 included $\$ 5.5$ million for the coordination of NOAA programs and activities in the Chesapeake Bay. Activities included targeted restoration, protection, and monitoring of vital habitats and fishery resources; synthesizing and delivering scientific data to support the management of oysters, blue crab, striped bass, and other ecologically and commercially important species; and operating and maintaining CBIBS to deliver information about the Bay to the public. CBIBS as such continues to provide essential foundations or baseline data for NCBO operations and resultant reports.

We have used information obtained from U.S. Integrated Ocean Observing System (U.S. IOOS) studies in our analysis. Direct use values have been documented by NOAA and organizations such as the Chesapeake Bay Foundation (CBF). These data, information, and capabilities support the forecasting of harmful algae blooms, identification of hypoxia, monitoring of pathogens such as Vibrio bacteria, and essential infrastructure and processes for ecological forecasts. The NCBO, for example, provides CBIBS data to weather forecast offices and the National Data 
Buoy Center (NDBC). The CBF uses the CBIBS system for both staff level scientific observation and analysis such as in the preparation of an annual Bay Report Card. Passive use values have been estimated-the CBF education program, for example, uses CBIBS field collected water quality parameters and CBIBS remotely sensed data in their Science, Technology, Engineering, and Mathematics (STEM) programs. CBIBS is introduced annually to over 1,000 secondary school students, their teachers, and principals, with the buoy system in particular allowing students to understand the concepts of stratification and eutrophication as it effects hypoxia. This is because the chlorophyll, bottom dissolved oxygen, and temperature sensors on some buoys augment data that students can collect from education vessel platforms such as the schooner Lady Maryland, Chesapeake Buyboats Mildred Belle and Half Shell, and Skipjacks Sigsbee and Minnie $V$.

Numerous authors (e.g., Altalo, 2006; Colgan, 2007; Kite-Powell, 2009; ERISS Corporation \& The Maritime Alliance, 2016) have also looked at the U.S. IOOS or similar observatories and estimated the value of their observations for the benefit of the public. Requirements to safeguard lives and protect property drive the need for relevant observations and environmental information. These rely on environmental forecast information for operations in revenue forecasting and load management to infrastructure siting and supply chain management. Altalo (2006) points out that market economics is a major driver when there is a need for internalizing environmental externalities to reduce impact on operations. Systems such as CBIBS improve environmental forecasts and reduce risks, thereby increasing value for operations, and provide baseline data for regulators. A partial list of users that depend on or benefit from CBIBS is provided in Table 2.

The present study is the first one to look at the value of the CBIBS system as a whole. It addresses the broader question concerning the system's overall economic value for other government agencies, academia, industry, and the American public. The Maryland Department of Natural Resources, for example, received funding from NCBO to maintain buoys in Maryland waters while the Virginia Institute of Marine Sciences was also funded to maintain buoys in Virginia waters. U.S. IOOS funding for universities and NCBO funding for not-for-profit organizations such as the Chesapeake Research Consortium (CRC) also contribute to some basic research that is accomplished by university investigators. The Mid-Atlantic Regional Association Coastal Ocean Observing System (MARACOOS), a 501(c)3 corporation, has been funded to help integrate and display CBIBS data in a way that is consistent with 
the U.S. IOOS. To support data integration with IOOS and acquire redundant server storage and access, CBIBS data are transmitted to servers maintained by the National Ocean Service, where processed data are inserted into a relational database and shared with MARACOOS and the NDBC. Data are quality controlled in accordance with the Quality Assurance of Real-Time Ocean Data (QARTOD) procedures that were developed by the NOAA U.S. IOOS Program, delivered to NDBC and appear on the Global Telecommunications Service within ten minutes of collection, and periodically transferred to the NOAA National Centers for Environmental Information for archiving. Finally, for profit companies such as Earth Resources Technology, Inc. (ERT) provide marine technicians to support many operational and maintenance tasks of CBIBS.

Such valuation research helps the Chesapeake Bay Program and organizations such as NCBO to define with accuracy and inventory the impact of observational systems such as CBIBS. It also provides an alternative to traditional discountedcash-flow (DCF) analysis which, when used alone, may be biased against valuing projects such as CBIBS that are dependent on congressional appropriations. Rather than forecast cash flows budget year by budget year and then discount these static forecasts at the opportunity cost of capital, we will apply a Monte Carlo model, thereby allowing the reader to visualize inherent risks and their impact upon the Chesapeake Bay Program. McGinty (2016), for instance, describes how weather forecasters can use Monte Carlo simulations to compute for reliable probabilities of hurricane tracks and thus improve the skill of hurricane forecasting.

The allocation of resources is a key driver in CBIBS utility. This paper, moreover, also considers the policy implications if CBIBS were to be decommissioned. ${ }^{1}$ A conservative salvage value for a CBIBS buoy-there are ten-is approximately $\$ 150,000$ as estimated by Dr. Kilbourne. Abandonment of the system, however, would negatively impact other agencies such as the NOAA U.S. IOOS Program, U.S. Coast Guard (USCG), and the National Park Service (NPS) as well as organizations such as MARACOOS and the CBF that use CBIBS directly. NOAA funded research programs, such as the Coastal and Ocean Modeling Testbed for example, have also relied on CBIBS data (in this case, to assess an estuarine hypoxia model) (Luettich et al., 2017).

${ }^{1}$ The Chesapeake Bay Office of NOAA Fisheries and especially Dr. Byron Kilbourne who is the lead oceanographer responsible for CBIBS provided data and information that was essential to the completion of this study. Dr. Kilbourne identified the value drivers used therein, and his expertise assisted in the identification of the appropriate distribution to be used for each variable. 


\begin{tabular}{|c|c|c|}
\hline Sample Organizations & Sector/Program & Funder \\
\hline $\begin{array}{l}\text { WMO Integrated Global } \\
\text { Observation System Region IV }\end{array}$ & $\begin{array}{l}\text { Global Ocean } \\
\text { Observing System }\end{array}$ & WMO \\
\hline $\begin{array}{l}\text { NDBC, Maryland Department of } \\
\text { Natural Resources (MD DNR), } \\
\text { USACE, USCG }\end{array}$ & $\begin{array}{l}\text { Federal, State, and } \\
\text { Local Government }\end{array}$ & $\begin{array}{l}\text { Department of } \\
\text { Defense, Department } \\
\text { of Commerce, State of } \\
\text { Maryland }\end{array}$ \\
\hline $\begin{array}{l}\text { University of Delaware, VCU, } \\
\text { Virginia Institute of Marine Science } \\
\text { (VIMS), University of Maryland Horn } \\
\text { Point Environmental Laboratory and } \\
\text { Chesapeake Biological Laboratory }\end{array}$ & Local Universities & $\begin{array}{l}\text { NOAA, Southeastern } \\
\text { Universities Research } \\
\text { Association (SURA) }\end{array}$ \\
\hline $\begin{array}{l}\text { CBF, Chesapeake Research } \\
\text { Consortium (CRC), Mid-Atlantic } \\
\text { Regional Association Coastal } \\
\text { Ocean Observing System } \\
\text { (MARACOOS), SURA, U.S. Power } \\
\text { Squadron }\end{array}$ & $\begin{array}{l}\text { Non-Governmental } \\
\text { Organizations }\end{array}$ & $\begin{array}{l}\text { NOAA, State of } \\
\text { Maryland, Private }\end{array}$ \\
\hline $\begin{array}{l}\text { AXYS Technologies, Caribbean } \\
\text { Wind, LLC, Dominion Virginia } \\
\text { Power, ERT, NORTEC, RPS Group, } \\
\text { WET Labs, etc. }\end{array}$ & Industry & $\begin{array}{l}\text { NOAA, Local } \\
\text { Universities }\end{array}$ \\
\hline $\begin{array}{l}\text { Commercial Fishermen, } \\
\text { Constellation Energy, Crowley } \\
\text { Maritime Corporation, Kingfisher } \\
\text { Environmental Services, Weather } \\
\text { Channel, Weather Underground }\end{array}$ & Industry & NOAA, Private \\
\hline Recreational Boaters & $\begin{array}{l}\text { Power Boats, Work } \\
\text { Boats, Sail Boats, } \\
\text { Kayaks, and other } \\
\text { water craft }\end{array}$ & Private \\
\hline
\end{tabular}

Table 2: CBIBS beneficiaries range from local recreational boaters to members of the World Meteorological Organization (WMO). 
CBIBS may be partitioned into five main areas for the analysis of future value drivers: i) programs that focus on marine operations, ii) programs that focus on university research and development, iii) recreation opportunities for communities, iv) protection of natural environments and features that are important to communities, and v) use by industry. Each of these would be described in terms of cash flows. CBIBS, for instance, supports the development of research and new sensors that assist in NOAA's Ocean Acidification Programs as well as of models that support the Ecological Forecasting Roadmap. The program must also plan and budget for risks that require unscheduled maintenance. Indeed, CBIBS has already experienced ten catastrophic losses since 2007-five collisions with vessels, ice damage to four buoys, and vandalism of one buoy. Table 3 below highlights value drivers for the CBIBS program that impact the number of parameters that are measured, up time, usage, and data quality.

Impacts or risks to the budget such as deficits (or surpluses) need to be understood for CBIBS to remain viable. If NCBO takes in more money than it spends in a given year, for example, the result could be a surplus for enhancing the existing CBIBS. The fiscal year 2017 CBIBS budget, for instance, has reduced funding for vessel services and the development of a data management system. Such anticipated changes could free up approximately $\$ 100,000$ which could be applied toward replacing aging CBIBS hardware or responding to system losses and contingencies. NOAA also requested $\$ 5.5 \mathrm{M}$ for the coordination of their programs and activities in the Chesapeake Bay region for 2017. It would seem then that programs such as CBIBS facilitate the transfer of funds, property, and services to the NOAA Chesapeake Bay Office from other federal agencies. We estimated that the transfers will not exceed $\$ 500,000$ per year.

The declining NCBO and stable CBIBS budgets are depicted in Figure 4. Based on an $\mathrm{R}^{2}$ of 0.003 , there is no clear association between the two. 


\begin{tabular}{|c|c|c|}
\hline Buoy Location & $\begin{array}{c}\text { Impact } \\
\text { (Period of Operation) }\end{array}$ & Description \\
\hline $\begin{array}{l}\text { Susquehanna } \\
\qquad(\mathrm{S})\end{array}$ & None (2008-2016) & $\begin{array}{l}\text { Buoy is visible from locations along the Harford } \\
\text { and Cecil County shorelines, including Havre de } \\
\text { Grace's Concord Point and Promenade area. }\end{array}$ \\
\hline Patapsco (SN) & 2008, 2010 (2008-2016) & $\begin{array}{l}\text { Buoy was struck by vessel, resulting } \\
\text { in significant hull damage and flooded } \\
\text { instruments. Buoy was vandalized. }\end{array}$ \\
\hline $\begin{array}{l}\text { Annapolis } \\
\text { (AN) }\end{array}$ & 2015 (2009-2016) & $\begin{array}{l}\text { Buoy accumulated ice on superstructure and } \\
\text { capsized in February } 2016 .\end{array}$ \\
\hline $\begin{array}{c}\text { Upper } \\
\text { Potomac (UP) }\end{array}$ & (2010-2016) & $\begin{array}{l}\text { Buoy was impaled by carbon fiber object. } \\
\text { There is a large hole in the hull. Buoy damage } \\
\text { estimated at } \$ 30,000 \text {. }\end{array}$ \\
\hline $\begin{array}{l}\text { Gooses Reef } \\
\qquad(\mathrm{GR})\end{array}$ & 2015 (2010-2016) & $\begin{array}{l}\text { Buoy accumulated ice on superstructure and } \\
\text { capsized in February } 2016 \text {. Owing to Hurricane } \\
\text { Matthew damage, it flooded internally, resulting } \\
\text { in low buoyancy which reduced resiliency of the } \\
\text { hull. Buoy damage estimated at } \$ 30,000 \text {. }\end{array}$ \\
\hline Potomac (PL) & 2015 (2008-2016) & $\begin{array}{l}\text { Buoy accumulated ice on superstructure and } \\
\text { capsized in February } 2016 .\end{array}$ \\
\hline $\begin{array}{l}\text { Stingray Point } \\
\qquad(\mathrm{SR})\end{array}$ & None (2008-2016) & $\begin{array}{l}\text { Located near Deltaville, VA and approximately a } \\
\text { mile offshore. }\end{array}$ \\
\hline York Spit (YS) & None (2016) & $\begin{array}{l}\text { Buoy is located near Perrin, VA at the mouth of } \\
\text { the York River. Maintenance activities involve the } \\
\text { CBIBS field and technical team in collaboration } \\
\text { with partners from NOAA Sanctuaries and the } \\
\text { VIMS. }\end{array}$ \\
\hline Jamestown (J) & 2015 (2007-2016) & $\begin{array}{l}\text { Buoy accumulated ice on superstructure and } \\
\text { capsized in February. }\end{array}$ \\
\hline $\begin{array}{l}\text { First Landing } \\
\qquad(\mathrm{FL})\end{array}$ & $\begin{array}{l}\text { 2008, 2010, 2012, } 2016 \\
\quad(2011-2016)\end{array}$ & $\begin{array}{l}\text { Buoy struck by vessel and relocated; another } \\
\text { relocation is planned. In October } 2016 \text {, } \\
\text { vessel collision damaged superstructure and } \\
\text { meteorological sensors; internal flooding } \\
\text { occurred during Hurricane Matthew. Buoy } \\
\text { damage estimated at } \$ 50,000 \text {. }\end{array}$ \\
\hline
\end{tabular}

Table 3: Attribute descriptions_CBIBS. Buoys collect and report information for up to 37 meteorological and oceanographic parameters. Details were obtained from http://buoybay.noaa.gov/. 


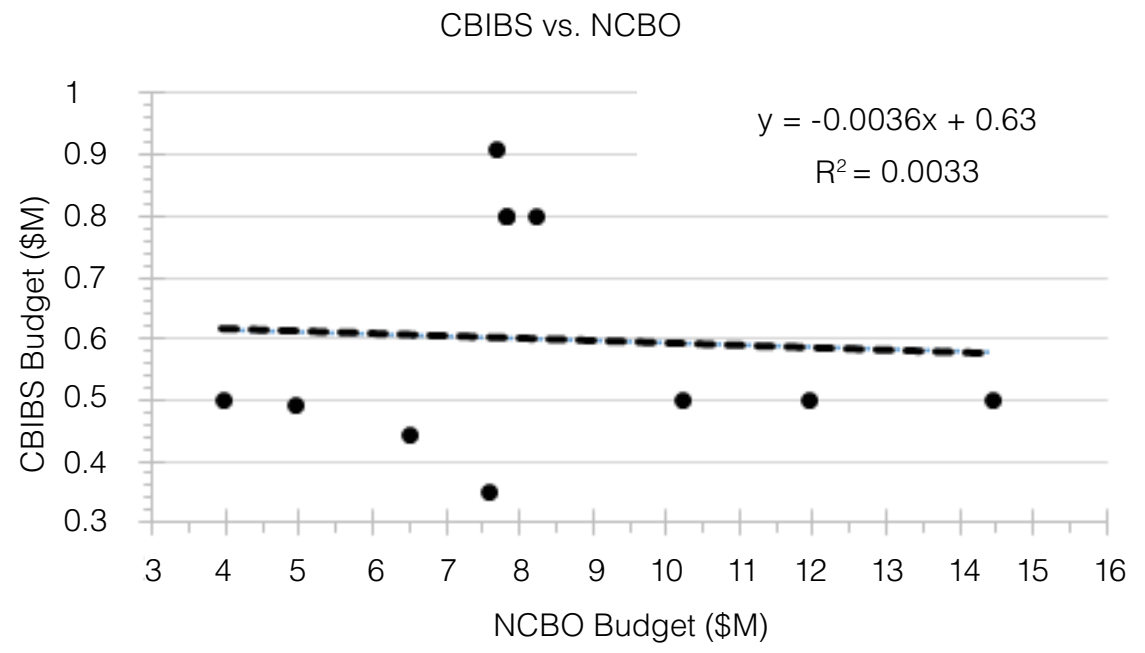

Figure 4: Budget graphic showing the correlation between the NCBO and CBIBS budgets.

\section{FINANCIAL MODELING USING MONTE CARLO SIMULATION}

For the Monte Carlo simulation, different types of distributions were reviewed, the best fit distribution was determined, and the data was inputted into the Monte Carlo model. The product used for running the simulation, @Risk Monte Carlo simulation software, contains more than 100 distributions for consideration in modeling variables. The distributions selected, and the rationale behind their selection, are discussed below.

Monte Carlo simulation performs risk analysis by building models of possible results by substituting a range of values - a probability distribution - for any factor that has inherent uncertainty. It then calculates results over and over, each time using a different set of random values from the probability functions. Depending upon the number of uncertainties and the ranges specified for them, a Monte Carlo simulation could involve thousands or tens of thousands of recalculations before it is complete. Monte Carlo simulation produces distributions of possible outcome values.

By using probability distributions, variables can have different probabilities of different outcomes occurring. Probability distributions are a much more realistic way of describing uncertainty in variables of a risk analysis.... 


\begin{abstract}
During a Monte Carlo simulation, values are sampled at random from the input probability distributions. Each set of samples is called an iteration, and the resulting outcome from that sample is recorded. Monte Carlo simulation does this hundreds or thousands of times, and the result is a probability distribution of possible outcomes. In this way, Monte Carlo simulation provides a much more comprehensive view of what may happen. It tells you not only what could happen, but how likely it is to happen. (Palisade, n.d.)
\end{abstract}

The Monte Carlo simulation for this study required the development of scenarios that included assumptions about the value drivers and factors that are critical to CBIBS's success. These value drivers relate to usage of the system by universities, industries, other agencies, and the general public. Random inputs (within realistic limits) were used to model CBIBS's costs and produce probable outcomes of value. A quantitative model of CBIBS activities as well as a "transfer equation" based on NOAA-derived information were developed. Some of the value factors in the transfer equation were found to follow a normal distribution while others followed a triangular or uniform one.

Distribution parameters for each input (e.g., the mean and standard deviation for inputs that follow a normal distribution) were then determined. For the triangular distribution, the minimum, maximum, and mean variables were found through a review of historical data as well as by relying upon the expertise and experience of Dr. Kilbourne. Likewise, the minimum and maximum values for the variables in constant probability uniform distribution were determined using historical data as well as CBIBS's executive expertise.

The value drivers are characterized by relevant distributions. Procurement of spare parts and buoy components, for example, was modeled using a triangular distribution with minimum costs of $\$ 493,000$ annually, most likely outflows of $\$ 800,000$, and maximum costs of $\$ 1,400,000$. This distribution and its parameters were determined by reviewing historical data as well as incorporating replacement costs; distribution was estimated using actual historical data ranging from a cost of components of $\$ 20,000$ when no exceptional events occur to the loss of three buoys like that which occurred in 2015 with a replacement cost of $\$ 450,000$.

Likewise, costs incurred by CBIBS were modeled as a triangular distribution based upon both historic costs and future projections. Buoy procurement is one example-the practice for CBIBS is to acquire buoys on a regular basis to replace worn or damaged units and have a small inventory of buoys and buoy parts 
available. Given the lack of correlation between CBIBS's needs and NCBO's budgets (given that the budget is set by Congress), however, variables such as R\&D expense, extended operations, and new products are funded based on remaining budgetary allotments available after costs of operations are covered and buoys are procured. These variables are also modeled using a uniform distribution.

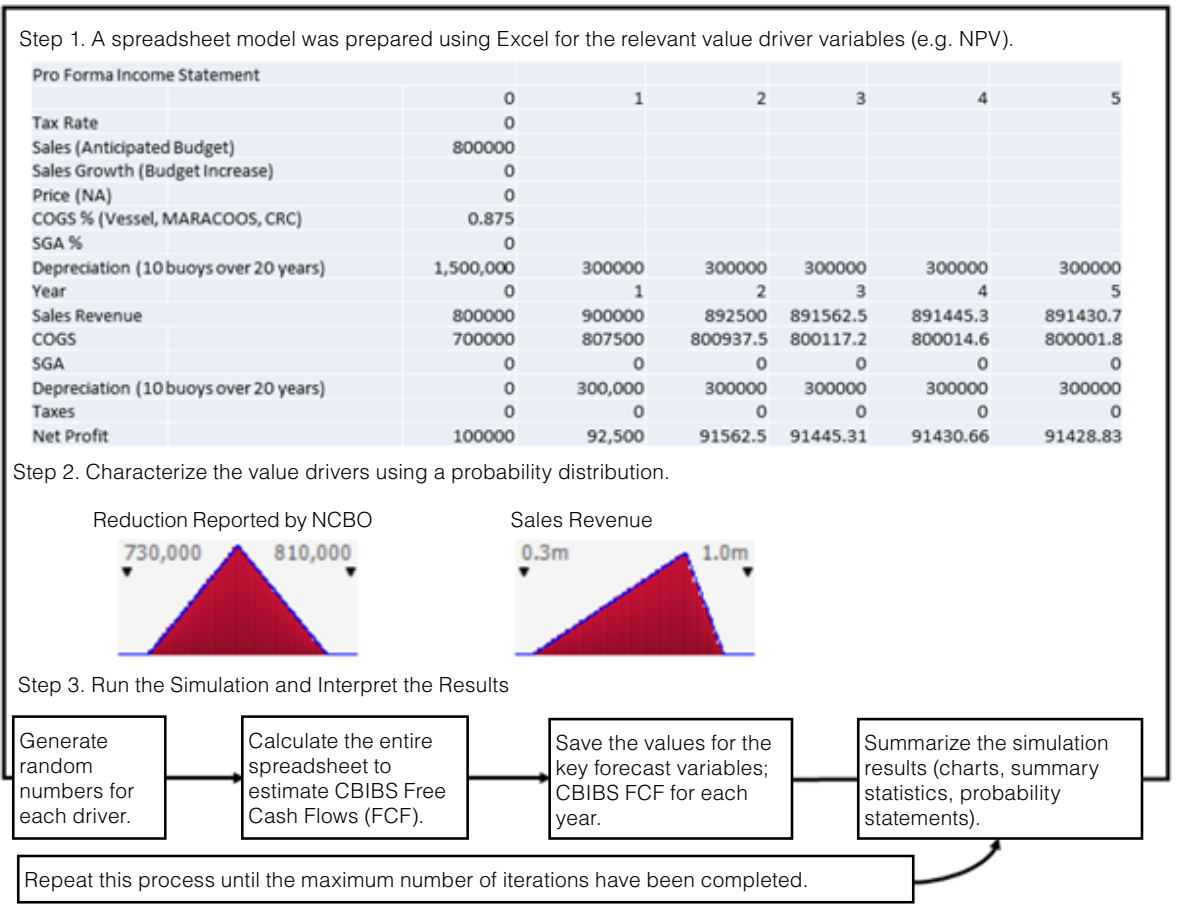

Figure 5: Monte Carlo Simulation flow diagram (adapted from Titman \& Martin, 2016). The simulation was run with incomplete value drivers as a student exercise. The importance here is in the process of determining value for a public good such as CBIBS.

\section{FINDINGS AND DISCUSSION}

The pro forma cost of operating CBIBS resulted in an NPV of $\$ 24,307.44$ and an IRR of $10 \%$ over the five-year period (2016-2020) of this study. ${ }^{2}$ Variables that

${ }^{2}$ The Office of Management and Budget (OMB) has had a real discount rate of seven percent for public investment and regulatory analyses since 1992. 
could be used by NCBO for budgeting were estimated using a simple Monte Carlo simulation based on historical trends and the following distributions for key variables (Table 4):

\begin{tabular}{|c|c|c|c|}
\hline \multirow{2}{*}{ Variable } & \multirow{2}{*}{ Expected Value } & \multicolumn{2}{|c|}{ Distributional Assumption } \\
\cline { 3 - 4 } & & Distribution & Parameter Range \\
\hline $\begin{array}{c}\text { Budget } \\
\text { appropriations }\end{array}$ & $\$ 800,000$ & Triangular & $\$ 351,000-\$ 912,000$ \\
\hline Costs & $\$ 770,000$ & Triangular & $\$ 740,000-\$ 800,000$ \\
\hline Buoy procurement & $\$ 150,000$ & Uniform & $\$ 150,000-\$ 300,000$ \\
\hline R\&D & $\$ 200,000$ & Uniform & $\$ 200,000-\$ 1,000,000$ \\
\hline Extended operations & $\$ 200,000$ & Uniform & $\$ 200,000-\$ 400,000$ \\
\hline New products & $\$ 200,000$ & Uniform & $\$ 200,000-\$ 800,000$ \\
\hline
\end{tabular}

Table 4: Monte Carlo simulation assumptions for CBIBS project.

The variables are as follows:

- Budget appropriations represents government funding allocated for NOAA and consequently to CBIBS every year

- Costs represents the projected annual operating expenses for CBIBS

- Buoy procurement is the line item for the cost of replacement buoys and replacement buoy parts

- $\quad R \& D$ represents research and development costs associated with ongoing work in search of new ways to enhance the effectiveness of the buoy program

- Extended operations is the line item for projected overtime costs

- New products represents the cost associated with procuring new technologies to enhance the value added by the buoy program

The simulation used 10,000 iterations to produce a distribution of projected cash flow for years 2016 through to 2020. The results are reported in Figure 6. 


\begin{tabular}{|l|l|l|}
\hline \multicolumn{2}{|c|}{ Simulation Summary Information } \\
\hline Workbook Name & 160907 CBIBs Monte Carlo data.xIsx \\
\hline Number of Simulations & 1 & \\
\hline Number of Iterations & 10000 \\
\hline Number of Inputs & 12 & \\
\hline Number of Outputs & 1 & \\
\hline Sample Type & Latin Hypercube \\
\hline Simulation Start Time & $9 / 7 / 2016$ 17:29 \\
\hline Simulation Duration & $0: 00: 05$ \\
\hline Random \# Generator & Mersenne Twister \\
\hline Random Seed & 127563525 \\
\hline
\end{tabular}

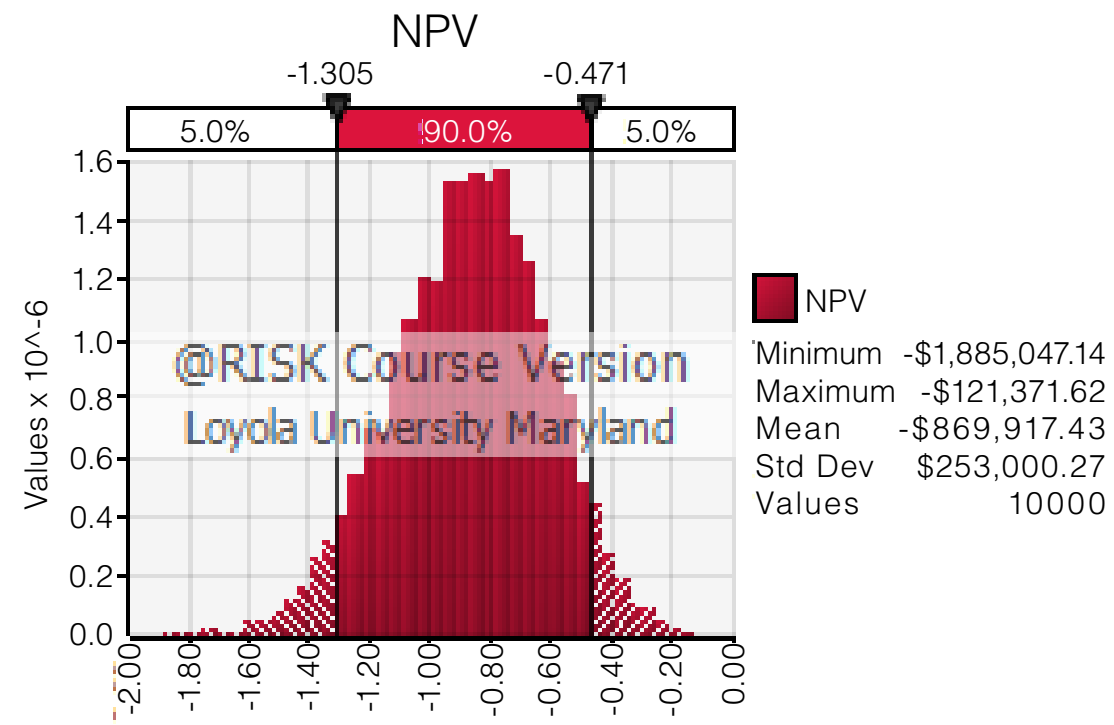

Values in Millions (\$) 


\begin{tabular}{|c|c|c|c|}
\hline \multicolumn{4}{|c|}{ Summary Statistics for NPV } \\
\hline Min & $(\$ 1,885,047.14)$ & $5 \%$ & $(\$ 1,304,761.15)$ \\
\hline Max & $(\$ 121,371.62)$ & $10 \%$ & $(\$ 1,207,151.67)$ \\
\hline Mean & $(\$ 869,917.43)$ & $15 \%$ & $(\$ 1,136,259.22)$ \\
\hline Std Dev & $\$ 253,000.27$ & $20 \%$ & $(\$ 1,084,178.91)$ \\
\hline Var & 64009139143 & $25 \%$ & $(\$ 1,037,992.17)$ \\
\hline Skew & -0.219 & $30 \%$ & $(\$ 995,729.74)$ \\
\hline Kurtosis & 2.897 & $35 \%$ & $(\$ 956,675.10)$ \\
\hline Median & $(\$ 858,026.36)$ & $40 \%$ & $(\$ 924,500.84)$ \\
\hline Mode & $(\$ 784,096.28)$ & $45 \%$ & $(\$ 890,222.31)$ \\
\hline Left X & $(\$ 1,304,761.15)$ & $50 \%$ & $(\$ 858,026.36)$ \\
\hline Left P & $5 \%$ & $55 \%$ & $(\$ 826,632.11)$ \\
\hline Right X & $(\$ 471,050.14)$ & $60 \%$ & $(\$ 792,572.10)$ \\
\hline Right P & $95 \%$ & $65 \%$ & $(\$ 763,378.93)$ \\
\hline Diff X & $\$ 833,711.01$ & $70 \%$ & $(\$ 730,094.76)$ \\
\hline Diff P & $90 \%$ & $75 \%$ & $(\$ 691,877.19)$ \\
\hline \#Errors & 0 & $80 \%$ & $(\$ 652,454.13)$ \\
\hline Filter Min & Off & $85 \%$ & $(\$ 605,992.93)$ \\
\hline Filter Max & Off & $90 \%$ & $(\$ 549,966.46)$ \\
\hline \#Filter & 0 & $95 \%$ & $(\$ 471,050.14)$ \\
\hline
\end{tabular}

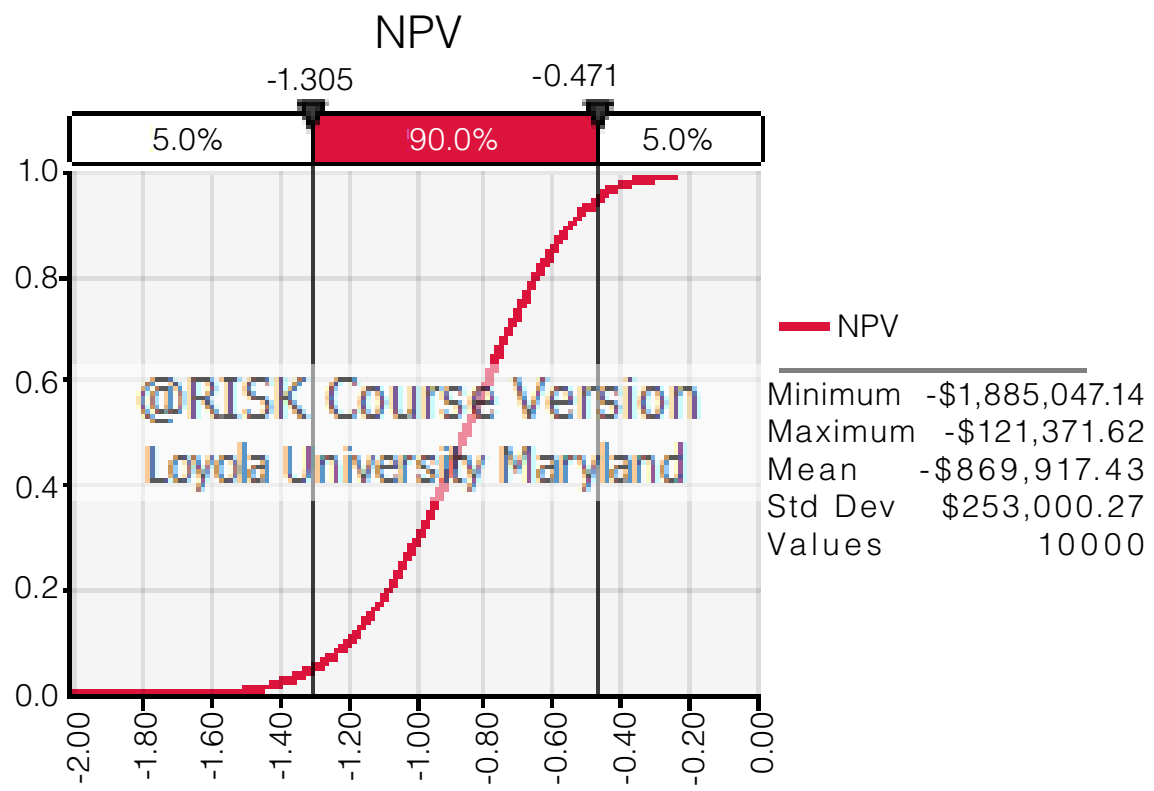

Values in Millions (\$)

Figure 6: Simulation results using @RISK Course Version with a spreadsheet NPV model. 
The average cost of running CBIBS is $\$ 869,917.43$ every year with a standard deviation of $\$ 253,000.27$. This compares favorably with an estimated created value of $\$ 4.6$ billion which in turn generates a positive NPV of $\$ 3.7$ billion. The simulation provides objective data on the value of CBIBS - the project is a benefit to multiple agencies, universities, and organizations.

Sensitivity analysis can help determine which variables have the greatest potential impact for CBIBS and therefore have the greatest chances of influencing project value. This Tornado diagram (see Figure 7) compares the relative importance of the variables-the $Y$-axis contains each type of uncertainty at base values and the $X$-axis contains the spread or correlation of the uncertainty to the studied output. Each uncertainty contains a horizontal bar and is ordered vertically from most to least impactful to show uncertainties with decreasing spread from the base values. The top five variables most critical to CBIBS are, not surprisingly, the budget appropriations for each of the five years under study. Cuts in these budgets create the largest impact on the value CBIBs is able to create for its constituents.

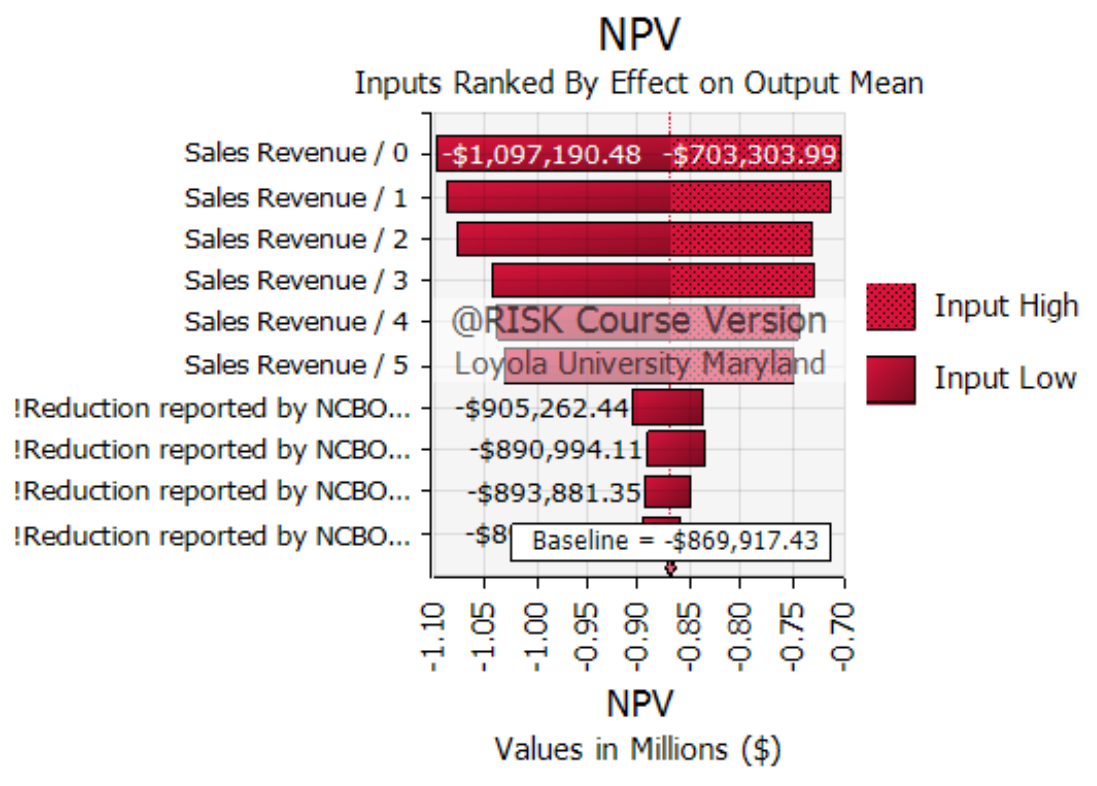

Figure 7. Tornado diagram for CBIBS. Each variable was independently considered for estimated net present value. 


\section{CONTRIBUTIONS OF THIS STUDY}

This student project suggests a methodology integrated with operations and management that can track CBIBS costs in a way not previously done by the agency. Using accurate and consistent cost information, the Monte Carlo simulation can be applied to help make informed investment decisions and especially to prepare better for the costs of unscheduled maintenance. This is particularly important since the budget is a congressional appropriation-the Congressional Budget Committee appreciates transparency in models such as the Monte Carlo simulation and can see its sophistication in modeling variables with realistic distributions. Finally, this work also provides tangible insights into the value of CBIBS for stimulating local economies.

The National Oceanic and Atmospheric Administration eventually deemed this student experiential learning project to be substantial and sophisticated enough to assist it in justifying its budget request. The study was thus submitted to Congress to help rationalize the allocations requested by the Chesapeake Bay Office of the NOAA. Monte Carlo simulation was also deemed to be a modeling approach that could be applied by NOAA managers for budget justifications in the future.

Working with live data in the classroom, moreover, helps students to see the challenges of actually gathering the data and developing a financial model for data analysis. It also enhances student learning and improves retention and recall of theory when presented with the opportunity to apply such in the future. Finally, the outcome of the study can be used to introduce new modeling techniques to agencies and then have those techniques be adopted eventually by them.

There is immediate value creation for the student and potentially for the organization when experiential learning is accomplished through projects that benefit particular organizations (an environmental one in this case). Students will typically have a better understanding of the challenges associated with completing a comprehensive analysis. They have the opportunity to contextualize it, and they report more success in transferring classroom learning to their work world. Employers gain workers who are exposed to new theories and technologies and therefore are more productive and require less management. Students with advanced skills thus increase their earning potential by developing and refining their capabilities. 


\section{ACKNOWLEDGEMENTS}

We would like to thank the Chesapeake Bay Office of NOAA Fisheries and especially Dr. Byron Kilbourne, who is the lead oceanographer responsible for CBIBS, for their efforts to provide data and information that was essential for the completion of this study.

\section{REFERENCES}

AACSB International. 2007. AACSB assurance of learning standards: An interpretation. Available at https://naspaaaccreditation.files.wordpress. com/2014/04/aacsb.pdf.

AACSB International. 2016. A collective vision for business education. Available at http://communications.aacsb.edu/files/amf_highroad_solution/workspace_43/ BEI_Report_Files/collective-vision-for-business-education.pdf.

Altalo, M. 2006. Applications of ocean forecast information for economic advancement in developed and developing societies. In E. P. Chassignet \& Jacques Verron (Eds.), Ocean weather forecasting: An integrated view of oceanography: 483-505. Dordrecht, The Netherlands: Springer.

Colgan, C. S. 2007. A guide to the measurement of the market data for the ocean and coastal economy in the National Ocean Economics Program. Monterey, CA: National Ocean Economics Program. Available at http://www.oceaneconomics. org/Download/Market_Guide.asp.

ERISS Corporation \& The Maritime Alliance. 2016. The ocean enterprise: $A$ study of US business activity in ocean measurement, observation, and forecasting. Silver Spring, MD: National Oceanic and Atmospheric Administration / U.S. Integrated Ocean Observing System. Available at https://cdn.ioos.noaa.gov/ media/2017/12/oceanenterprise_feb2017_secure.pdf.

Jamison, D. T., Hanushek, E. A., Jamison, E. A., \& Woessmann, L. 2008. Education and economic growth: It's not just going to school, but learning something while there that matters. Education Next, 8(2): 62-71. 
Kim, C., Tamborini, C. R., \& Sakamoto, A. 2015. Field of study in college and lifetime earnings in the United States. Sociology of Education, 88(4): 320-339.

Kite-Powell, H. L. 2009. Economic considerations in the design of ocean observing systems. Oceanography, 22(2): 44-49.

Kuh, G. D. 2016. Making learning meaningful: Engaging students in ways that matter to them. New Directions for Teaching and Learning, 145: 49-56.

Luettich Jr., R. A., Wright, L. D., Nichols, C. R., Baltes, R., Friedrichs, M. A., Kurapov, A., van der Westhuysen, A. J., Fennel, K., \& Howlett, E. 2017. A test bed for coastal and ocean modeling. Eos, 98. Available at https://eos.org/projectupdates/a-test-bed-for-coastal-and-ocean-modeling.

McGinty, J. C. 2016. As forecasts go, you can bet on Monte Carlo. The Wall Street Journal, August 12. Available at https://www.wsj.com/articles/as-forecasts-goyou-can-bet-on-monte-carlo-1470994203 (accessed August 12, 2016).

National Park Service. n.d. Captain John Smith Chesapeake National Historic Trail. Available at http://smithtrail.net/ (accessed July 25, 2016).

NOAA Budget Office. n.d. Historical budget information. Available at http://www. corporateservices.noaa.gov/nbo/historical_budget.html (accessed July 27, 2016).

Palisade. n.d. How Monte Carlo simulation works. Available at https://www. palisade.com/risk/monte_carlo_simulation.asp.

Phillips, S., \& McGee, B. 2014. The economic benefits of cleaning up the Chesapeake: A valuation of the natural benefits gained by implementing the Chesapeake clean water blueprint. Chesapeake Bay Foundation. Available at https:// conservationtools-production.s3.amazonaws.com/library_item_files/1328/1219/ FINALBenefitsOfTheBlueprint_TechReport_and_Summary20141002.pdf.

Stretcher, R. 2015. Net present value simulation: A case study. Journal of Business Strategies, 32(2): 139-150.

Tamborini, C. R., Kim, C., \& Sakamoto, A. 2015. Education and lifetime earnings in the United States. Demography, 52(4): 1383-1407. 
Titman, S., \& Martin, J. D. 2016. Valuation: The art and science of corporate investment decisions (3rd ed.). Boston, MA: Pearson.

Wheeler, T. 2012. Bay "smart" buoys scuttled by Obama. The Baltimore Sun, February 17. Available at http://articles.baltimoresun.com/2012-02-17/features/ bal-bay-smart-buoys-face-budget-cut-20120217_1_buoys-oyster-restoration-bayprogram (accessed July 27, 2016).

Winston, W. L. 1996. Simulation modeling using@Risk. Belmont, CA: Duxbury Press.

Karyl B. Leggio is Professor of Finance at Loyola University Maryland. She received her Ph.D. at the University of Kansas, her MBA at East Tennessee State University, and her undergraduate degree from Virginia Tech. Her primary area of research is in deregulating industries, specifically in the area of risk management. Additional avenues of active research are in the areas of real options, corporate restructuring, mergers, and individual risk management. Dr. Leggio has been awarded numerous grants for her research projects as well as being an award-winning teacher. She previously served as Dean of the Sellinger School of Business (2008-2014).

C. Reid Nichols is the president of Marine Information Resources Corporation, a Maryland veteran-owned small business. He is a physical oceanographer with an M.S. from North Carolina State University and an M.B.A. in international business from Loyola University Maryland. He has served as a physical oceanographer for the National Oceanic and Atmospheric Administration and currently provides applied oceanographic solutions to a variety of commercial and government customers. Nichols joined the U.S. Marine Corps Reserves in 1977 as a combat engineer and, after commissioning, served in positions as platoon, company, and battalion commander and then as a senior staff officer until his retirement in 2011 as a colonel. 